\title{
The Influence of Some Soil and Climatic Factors on Sapogenin Yields of Dioscorea ${ }^{1}$
}

\author{
Franklin W. Martin and Herminio Delpin ${ }^{2}$
}

\section{INTRODUCTION}

The agronomic requirements of the sapogenin-bearing yams (Dioscorea spp.) have been studied at this Station over a period of 12 years $(1,2,3,4) .^{3}$ During this period we have noticed luxuriant foliage when the crop was grown in light, well-drained soils, and slow growth when it was grown in heavy clays. With the belief that good drainage and high organic content of the soil were necessary for high sapogenin yields, we have routinely prepared the planting field by incorporating cachaza (sugarcane filter-press cake) into ridges of soil. Small plants were transplanted from nursery to the top of the ridge. To test the value of such practices and to gain more experience with the influence of climate and soil, we have made several tests reported herein.

\section{MATERIALS AND METHODS}

In one experiment, effects of method of soil preparation were tested on three different soils of similar rainfall distribution in Mayagüez. The soils were a heavy clay of moderate fertility (Cialitos), an aggregated clay of low fertility but excellent internal drainage (Nipe), and an alluvial silty loam (Toa). The planting beds were at ground level, or consisted of 6to 8-inch ridges with or without cachaza below them. Plants were spaced at 1-foot intervals in rows 4 feet apart. One clonal variety each of $D$. composita and $D$. floribunda was planted in a randomized-block arrangement with six replications. All were propagated from single-leaf stem cuttings. The experiment was harvested by hand-digging after 2 years of field growth.

In a second experiment effects of soil and location were tested in three widely separated locations (Isabela, Adjuntas, Corozal) with distinctive climatic conditions. One soil was a rich loam in the coastal plateau (420 feet) of medium rainfall (Coto loam, Isabela). The second was a heavy clay at a high elevation (2,200 feet) under heavy rainfall (Toa clay loam,

${ }^{1}$ In cooperation with the USDA New Crops Research Branch, Beltsville, Md. We also gratefully acknowledge the assistance of the Commonwealth Agricultural Experiment Station, and in particular the help of the Directors of the Substations at Isabela, Corozal, and Adjuntas.

${ }^{2}$ Plant Geneticist and Agronomist, respectively, Federal Experiment Station, Crops Research Division, Agricultural Research Service, U.S. Department of Agriculture, Mayagüez, P.R.

${ }^{3}$ Italic numbers in parenthesis refer to Literature Cited, p. 265. 
Adjuntas). The third was a very heavy acid clay at medium elevation (500 feet) with fairly heavy rainfall (Lares clay, Corozal). Two openpollinated varieties of $D$. floribunda and one of $D$. composita, each propagated by two methods-tuber pieces, one-node stem cuttings-were compared. The experiment consisted of four replications. After 3 years of field growth, tubers were harvested by lifting and turning them with a moldboard plow. Tuber pieces were then raked from the loose soil.

The plantings were supported by concrete poles strung with strong wire and string (first experiment) or individual 6-foot bamboo poles (second). All plots were treated with about 1,000 pounds per acre per year of mineral fertilizer. Weeding and insecticidal treatments were made as necessary.

Freshly dug tubers were washed and weighed. Representative samples from the first experiment were taken for analysis by the method of Morris, et al. (5). Tubers of the second experiment were crushed in a hammer mill, and samples of the resulting mixture were taken.

\section{RESULTS}

\section{FIRST EXPERIMENT}

Plants in the soil-preparation experiment were severely set back by a drought during the first season of growth. Nevertheless, recovery and growth were excellent during the second year. Analysis of variance showed significant differences in yields associated with the variables tested: Methods of soil preparation, soil type, and species (table 1).

Plants in ground-level beds outyielded plants in ridges in all yield measurements. We attribute this to the better protection against drought that the young plants received. However, significant interactions among treatment and species showed that $D$. composita was less influenced by soil preparations than was $D$. floribunda. Higher yields were associated with well-drained soil. The highest yields occurred in Nipe clay, a soil that provides a loose, granular growth medium but is otherwise infertile. Differences in percentage sapogenin, although significant, were not statistically related to soil type or soil preparation. Fresh and dry yields of the two species were significantly different, although total sapogenin yields were quite similar. This can be explained as a result of the negative correlation between tuber size and percentage sapogenin that exists between the species (1).

\section{SECOND EXPERIMENT}

Yields of fresh tubers and sapogenin content were significantly higher in Isabela than in Corozal or Adjuntas for both species of Dioscorea, but percentages of sapogenin were not significantly influenced by location. 
D. composita significantly outyielded $D$. floribunda at all locations. The two varieties of $D$. floribunda did not differ, and data were therefore averaged (table 2). Sapogenin percentages were slightly but significantly higher in $D$. composita than in $D$. floribunda. The reverse has generally been true in other experiments. Techniques of propagation did not influence yields in any respect.

Yields of the two species were affected similarly by location. There were no significant interactions of species with locations in the analysis. How-

TABLE 1.-Effects of method of soil preparation, location, and species on Dioscorea yields ${ }^{1}$

\begin{tabular}{|c|c|c|c|c|}
\hline \multirow{2}{*}{ Item } & \multicolumn{4}{|c|}{ Yield } \\
\hline & Fresh & Dry & Sapogenin & Sapogenin \\
\hline & kg./acre & kg./acre & kg./acre & Percent \\
\hline \multirow{2}{*}{\multicolumn{5}{|c|}{ Effects of location: }} \\
\hline & & & & \\
\hline Nipe clay & $4,637 \mathrm{a}$ & $1,782 \mathrm{a}$ & $68.0 \mathrm{a}$ & $3.82 \mathrm{ab}$ \\
\hline Toa silty loam & $3,032 \mathrm{a}$ & $1,375 \mathrm{a}$ & $54.8 \mathrm{a}$ & $3.98 \mathrm{a}$ \\
\hline Cialitos clay & $1,978 \mathrm{~b}$ & $719 \mathrm{~b}$ & $26.8 \mathrm{~b}$ & $3.73 \mathrm{~b}$ \\
\hline \multicolumn{5}{|c|}{ Effects of soil preparation: } \\
\hline \multicolumn{5}{|c|}{ Method of soil preparation- } \\
\hline Flat bed, no cachaza & $4,058 \mathrm{a}$ & 1,461 a & $57.98 \mathrm{a}$ & $3.97 \mathrm{a}$ \\
\hline Ridged bed, cachaza & $3,580 \mathrm{ab}$ & $1,304 \mathrm{a}$ & $48.90 \mathrm{ab}$ & $3.75 \mathrm{~b}$ \\
\hline Ridged bed, no cachaza & $3,145 \mathrm{~b}$ & $1,110 \mathrm{~b}$ & $42.70 \mathrm{~b}$ & $3.85 \mathrm{ab}$ \\
\hline \multicolumn{5}{|l|}{ Effects of species: } \\
\hline Species & & & & \\
\hline D. composita & $4,194 \mathrm{a}$ & $1,419 \mathrm{~b}$ & $51.2 \mathrm{a}$ & $3.61 \mathrm{~b}$ \\
\hline D. floribunda & $2,996 \mathrm{~b}$ & $1,165 \mathrm{a}$ & $48.6 \quad \mathrm{a}$ & $4.17 \mathrm{a}$ \\
\hline
\end{tabular}

${ }^{1}$ Means not followed by the same letter are significantly different from each other $(p=.05)$.

ever, varieties and propagation treatments significantly interacted for fresh weight, but not for total or percentage sapogenins. These interactions were attributable to the superior growth of $D$. composita from stem versus tuber cuttings, whereas the opposite occurred in D. floribunda.

When commercially milled samples were compared with those processed in the laboratory, the latter were found to be on the average 0.40-percent higher than the former in sapogenin content. Moreover, species differences in sapogenin content were not significant in the latter series of tests. These attenuated differences do not affect the conclusions drawn on the basis of total sapogenin yields. Correlation between mill-processed and lab-processed samples was only +0.23 , although means showed similar trends. 
We suspect that some loss of carbohydrate occurred during the waiting period for commercial tests, and that the hammer mill did not give as random a sample as would be desired.

Total sapogenin contents of $D$. composita were at commercially valuable levels in all locations, but those of $D$. floribunda were somewhat low. All yields were somewhat lower than those obtained from small, experimental plantings in Mayagüez (4).

TABLe 2.-Yields of 3-year-old Dioscorea tubers at 3 sites in Puerto Rico ${ }^{1}$

\begin{tabular}{|c|c|c|c|c|c|}
\hline \multirow{2}{*}{ Site } & \multirow{2}{*}{ Species } & \multirow{2}{*}{$\begin{array}{c}\text { Method of } \\
\text { propagation }\end{array}$} & \multicolumn{3}{|c|}{ Yield } \\
\hline & & & Fresh tuber & Sapogenin $^{2}$ & Sapogenin $^{3}$ \\
\hline \multirow{5}{*}{ Isabela } & & & kg./acre & kg./acre & Percent \\
\hline & D. composita & Tubers & $11,400 \mathrm{~b}$ & $139.5 \mathrm{bc}$ & $6.53 \mathrm{bc}$ \\
\hline & & Stems & $19,200 \mathrm{a}$ & $226.5 \mathrm{a}$ & $6.29 \mathrm{bcd}$ \\
\hline & D. floribunda & Tubers & $8,310 \mathrm{bc}$ & $100.5 \mathrm{~cd}$ & $5.23 \mathrm{e}$ \\
\hline & & Stems & $7,920 \mathrm{c}$ & $99.2 \mathrm{~cd}$ & $5.42 \mathrm{de}$ \\
\hline \multirow[t]{4}{*}{ Corozal } & D. composila & Tubers & $10,950 \mathrm{bc}$ & $120.5 \mathrm{bc}$ & 5.87 bede \\
\hline & & Stems & $16,250 \mathrm{a}$ & $163.6 \mathrm{ab}$ & $5.37 \mathrm{de}$ \\
\hline & D. floribunda & Tubers & $4,070 \mathrm{~cd}$ & 51.6 de & 5.68 ede \\
\hline & & Stems & $2,340 \mathrm{~d}$ & $31.1 \mathrm{e}$ & 5.75 ede \\
\hline \multirow[t]{4}{*}{ Adjuntas } & D. composita & Tubers & 8,120 bc & $126.6 \mathrm{bc}$ & $8.29 \mathrm{a}$ \\
\hline & & Stems & $10,150 \mathrm{bc}$ & $120.5 \mathrm{bc}$ & $6.34 \mathrm{bed}$ \\
\hline & D. floribunda & Tubers & $4,210 \mathrm{~cd}$ & $65.7 \mathrm{de}$ & $6.75 \mathrm{~b}$ \\
\hline & & Stems & $2,330 \mathrm{~d}$ & $33.3 \mathrm{e}$ & 6.20 bcde \\
\hline
\end{tabular}

${ }^{1}$ Means not followed by the same letter are significantly different $(p=.05)$.

${ }^{2}$ Sapogenin yields estimated from fresh weight and percentage sapogenin, without measuring dry weights.

${ }^{3}$ Determined from samples taken from hammer mill during commercial processing.

\section{DISCUSSION}

The experimental results herein show that locational differences (climate and soil) exert strong influences on Dioscorea yields. In the experiment with methods of soil preparation, no special preparation of ridges or incorporation of organic material was necessary, as the plots themselves were well-drained. Under such conditions plants in level beds probably are not damaged as much by drought as are plants in ridges, especially during the first few months after transplanting. This same experiment showed that, in three areas of similar rainfall, highest yields were obtained in the least fertile but best-drained soil. As in previous experiments, D. composita outyielded $D$. floribunda. 
In the locations experiment, soil and climatic influences could not be separated. Nevertheless, a trend of decreasing yields was noted with increased altitude, heavier soil, and heavier rainfall. The rich, loamy soil of Isabela produced outstanding yields. It would be interesting to determine whether yields in such a good soil could be further increased by dry-season irrigation.

Of the various characteristics measured, percentage yield seemed to be the most stable. Although environment doubtless influences sapogenin production, the high percentage yields of $D$. composita suggest that growing conditions at all of the three locations were favorable for sapogenin development. The percentage yields were similar at the three locations, and, in all cases, total production of sapogenin was influenced more by variation in fresh-weight yields than in sapogenin percentages.

\section{SUMMARY}

Plants of two sapogenin-bearing Dioscorea species propagated by two different techniques, were tested at different locations in Puerto Rico over a 3-year period. In an experiment at Mayagüez plants grew best in a loose, well-drained soil, planted on flat beds rather than ridges, and without the addition of organic material (cachaza). In plots at Isabela, Corozal, and Adjuntas sapogenin yields were higher in the Isabela loam than in the heavier clay soils at the other locations. Plants propagated from stem cuttings gave better results in $D$. floribunda plantings; propagations from tuber pieces gave better results with $D$. composita.

In these trials the propagation method and the effects of climate and soil influenced plant growth and tuber yields, but had little effect on the percentage of sapogenin developed in the tubers. Location effects on total sapogenin production resulted in most cases from differences in tuber yield, rather than in percentage sapogenin.

These were the largest controlled experiments conducted with sapogeninbearing species in Puerto Rico. Although these tests indicate that they are satisfactorily adapted to a wide range of conditions, it is clear that best yields are obtained in good, well-drained soils. Sapogenin yields were sufficiently high to be commercially valuable in all locations tested.

\section{RESUMEN}

Se probaron dos especies de Dioscorea propagadas mediante dos técnicas distintas en diferentes sitios de Puerto Rico, por un período de 3 años. En un experimento en Mayagüez se demostró que las plantas crecieron mejor cuando se sembraron a ras de tierra sin hacer lomos especiales, en suelos sueltos con buen desagüe, y sin incorporar materia orgánica (cachaza). Los resultados de las siembras experimentales hechas en Isabela, 
Corozal y Adjuntas revelaron que los rendimientos de sapogenina fueron mayores en la marga de Isabela que en los suelos más pesados y arcillosos de los otros lugares.

En cuanto a los métodos de propagación que se estudiaron, las plantas propagadas por esquejes de tallo dieron mejores resultados en las siembras de $D$. floribunda, mientras que las propagadas por pedazos de tubérculo resultaron mejor en el caso de $D$. composita.

En estas pruebas, los métodos de propagación que se usaron, el tipo de suelo y el clima predominate afectaron el crecimiento y el peso de los tubérculos, pero muy poco fue el efecto que ejercieron sobre el porcentaje de sapogenina que se desarrolló en los tubérculos. Los efectos de la localización sobre la producción total de sapogenina se reflejaron mayormente en las diferencias en el rendimiento de tubérculos más bien que en el porcentaje de sapogenina producida.

Estos fueron los experimentos controlados más extensos que se han llevado a cabo en Puerto Rico con especies de ñames medicinales. Las pruebas indican que aunque el ñame puede adaptarse a condiciones varias, es obvio que los mejores rendimientos se obtienen en suelos sueltos con buen desagüe. En todos los lugares en que se probaron estas dos especies de ñame, los rendimientos de sapogenina fueron lo suficientemente altos como para tener un valor comercial.

\section{LITERATURE CITED}

1. Cruzado, H. J., Delpín, H., and Roark, B. A., Sapogenin production in relation to age of tuber in two Discorea species, Turrialba 15: 25-8, 1965.

2. Cruzado, H. J., Delpín, H., and Martin, F. W., Effect of fertilizers on the sapogenin yields of Dioscorea composita in Puerto Rico, J. Agr. Univ. P.R. 49 (2): 254-8, 1965.

3. Kennard, W. C., and Morris, M. P., Influence of cultural practices on tuber yields and sapogenin content of Dioscorea floribunda, Agron. J. 48: 485-7, 1956.

4. Martin, F. W., Cabanillas, E., and Gaskins, M. H., The economics of the sapogenin-bearing yam as a crop plant in Puerto Rico, J. Agr. Univ. P.R. 50 (1): 53-64, 1966.

5. Morris, M. P., Roark, B. A., and Cancel, B., Simple procedure for the routine assay of Dioscorea tubers, J. Agr. Food Chem. 6: 856-8, 1958. 